\title{
Thioalkalimicrobium cyclicum sp. nov. and Thioalkalivibrio jannaschii sp. nov., novel species of haloalkaliphilic, obligately chemolithoautotrophic sulfur-oxidizing bacteria from hypersaline alkaline Mono Lake (California)
}

\footnotetext{
${ }^{1}$ Institute of Microbiology، Russian Academy of Science, Prospect 60-let Octyabrya 7/2, 117811 Moscow, Russia

2 Jet Propulsion Laboratory/California Institute of Technology, Pasadena, CA, USA

${ }^{3}$ Kluyver Institute of Biotechnology, TU Delft, Julianalaan 67, 2628 BC Delft, The Netherlands
}

\author{
Dimitry Yu. Sorokin, ${ }^{1,3}$ Vladimir M. Gorlenko, ${ }^{1}$ Tat'yana P. Tourova, $^{1}$ \\ Alexandre I. Tsapin, ${ }^{2}$ Kenneth H. Nealson ${ }^{2}$ and Gijs J. Kuenen ${ }^{3}$ \\ Author for correspondence: Dimitry Yu. Sorokin. Tel: +7 95 1350109. Fax: + 7951356530. \\ e-mail: soroc@inmi.da.ru
}

\begin{abstract}
Two strains of haloalkaliphilic, obligately autotrophic, sulfur-oxidizing bacteria were isolated from the oxygen-sulfide interface water layer of stratified alkaline and saline Mono Lake, California, USA. Strain ALM $1^{\mathrm{T}}$ was a dominant species in enrichment on moderate-saline, carbonate-buffered medium (0.6 M total $\mathrm{Na}^{+}, \mathrm{pH} \mathrm{10)}$ with thiosulfate as an energy source and nitrate as a nitrogen source. Cells of ALM $1^{\top}$ are open ring-shaped and are non-motile. It has a high growth rate and activity of thiosulfate and sulfide oxidation and very low sulfur-oxidizing activity. Genetic comparison and phylogenetic analysis suggested that ALM $1^{\top}\left(=\right.$ DSM $\left.14477^{\top}=J C M 11371^{\top}\right)$ represents a new species of the genus Thioalkalimicrobium in the $\gamma$-Proteobacteria, for which the name Thioalkalimicrobium cyclicum sp. nov. is proposed. Another Mono Lake isolate, strain ALM $2^{\top}$, dominated in enrichment on a medium containing $2 \mathrm{M}^{\text {total }} \mathrm{Na}^{+}$ (pH 10). It is a motile vibrio which tolerates up to $4 \mathrm{M} \mathrm{Na}^{+}$and produces a membrane-bound yellow pigment. Phylogenetic analysis placed ALM $2^{\top}$ as a member of genus Thioalkalivibrio in the $\gamma$-Proteobacteria, although its DNA hybridization with the representative strains of this genus was only about $30 \%$. On the basis of genetic and phenotypic properties, strain ALM $2^{\top}$ (= DSM $1^{14478}{ }^{\top}=J^{\prime} C^{\prime} 1^{1372}$ ) is proposed as Thioalkalivibrio jannaschii sp. nov.
\end{abstract}

Keywords: haloalkaliphilic sulfur-oxidizers, soda lakes, Mono Lake, Thioalkalimicrobium, Thioalkalivibrio

\section{INTRODUCTION}

Colourless sulfur-oxidizing bacteria represent an important part of microbial community in natural and some industrial habitats. Until recently, known sulfuroxidizing bacteria included neutrophilic and acidophilic species with possible $\mathrm{pH}$ range for stable growth between 2 and 8 (Kelly, 1989; Kuenen et al., 1992). Natural environments with high alkalinity and stable

Published online ahead of print on 14 December 2001 as DOI 10.1099/ijs.0.02034-0.

The GenBank accession numbers for the 165 rDNA sequence of strains ALM $1^{\top}$ and ALM $2^{\top}$ are AF329082 and AF329083, respectively. alkaline $\mathrm{pH}$ are represented by saline soda lakes, and recent intensive microbiological investigation of these habitats has revealed the presence of alkaliphilic bacteria belonging to various physiological groups (Jones et al., 1998; Zavarzin et al., 1999). In particular, it became clear that there exists a third, haloalkaliphilic, group of sulfur-oxidizing bacteria, which includes both heterotrophic (Sorokin et al., 1996) and obligately autotrophic (Sorokin et al., 2000b) representatives. Overall, more than 80 strains of alkaliphilic, obligately autotrophic, sulfur-oxidizing strains have been isolated and characterized (Sorokin et al., 2001a) from the volcanic soda lakes in Kenya and from the shallow soda lakes in dry steppes of the south-east 
Siberia and Mongolia. In general, these bacteria differ from the well-known neutrophilic species by their ability to grow optimally at $\mathrm{pH}>9$ and up to $10 \cdot 5-10 \cdot 6$ in media strongly buffered by a sodium bicarbonate/ carbonate mixture. All these bacteria have been assigned into two new genera Thioalkalimicrobium and Thioalkalivibrio in the $\gamma$-Proteobacteria (Sorokin et al., 2001a). The two genera differ from each other in many aspects of the growth kinetics, metabolic activity and genetics. In general, the genus Thioalkalimicrobium includes fast-growing species with high activity of thiosulfate and sulfide oxidation but relatively low salt tolerance. Most of the strains were obtained from the low-mineralized steppe soda lakes. The genus is a member of the Thiomicrospira cluster. In contrast, the genus Thioalkalivibrio is represented by the slowgrowing but more salt-tolerant organisms isolated mostly from the highly concentrated Kenyan soda lakes. Some of the isolates were even capable of growth in saturated soda brines. The genus Thioalkalivibrio is related to sulfur purple bacteria of the genus Ectothiorhodospira (Trüper \& Schlegel, 1964). This genus also includes several strains capable of growth with thiocyanate as electron donor and nitrogen source (Sorokin et al., 2001b) which form two new Thioalkalivibrio species (Sorokin et al., 2002). In this paper we describe two new species of haloalkaliphilic, obligately chemolithoautotrophic, sulfuroxidizing bacteria isolated from the stratified, alkaline and saline Mono Lake in California, USA.

\section{METHODS}

Sampling. Water samples were collected in July 1999 from the sulfide-oxygen interface layer (depth 19-25 m) at the deepest point $(48 \mathrm{~m})$ of Mono Lake, California, using 51 sampling bottles. The mean $\mathrm{pH}$ and total salinity values of the Mono Lake water were 9.8 and $80 \mathrm{~g} \mathrm{l}^{-1}$, respectively. The $\mathrm{HS}^{-}$concentration decreased upwards from several hundred micromolar in the anaerobic layer to several micromolar in the upper part of the interface layer. The samples were brought into a laboratory within $5 \mathrm{~h}$ of collection and kept at $4{ }^{\circ} \mathrm{C}$ until use.

Media and growth conditions. Enrichment for and cultivation of aerobic alkaliphilic sulfur bacteria was performed using a mineral medium strongly buffered by $\mathrm{NaHCO}_{3} / \mathrm{Na}_{2} \mathrm{CO}_{3}\left(0 \cdot 6-4 \mathrm{M}\right.$ total $\left.\mathrm{Na}^{+}\right)$at $\mathrm{pH} 10-10 \cdot 1$, as described previously (Sorokin et al., 2001a). Thiosulfate $(40-80 \mathrm{mM})$ served as the energy source and nitrate $(5 \mathrm{mM}$ as $\mathrm{KNO}_{3}$ ) as the nitrogen source. Solid alkaline media with final salt concentrations 0.6 and $2 \mathrm{M}$ total $\mathrm{Na}^{+}$were prepared by $1: 1$ mixing of $4 \%$ agar and double-strength mineral base at $50{ }^{\circ} \mathrm{C}$. Enrichments for denitrifying sulfur bacteria were performed in $100 \mathrm{ml}$ serum bottles with butyl rubber stoppers filled with $50 \mathrm{ml}$ of alkaline base with $20 \mathrm{mM}$ thiosulfate and $20 \mathrm{mM}$ nitrate. Anaerobiosis was achieved by five cycles of evacuation-flushing with argon.

Activity tests. The activity tests were performed with washed cells obtained from batch cultures grown at $\mathrm{pH} 10$ with thiosulfate. Cells were harvested by centrifugation, washed twice with soda buffer and resuspended in the same buffer at $20 \mathrm{mg}$ protein $\mathrm{ml}^{-1}$ and kept on ice. This concentrated suspension was diluted 100-1000 times immediately before experiments. The $\mathrm{pH}$ influence on the activity of thiosulfate oxidation was tested with an oxygen electrode as described previously (Sorokin et al., 2001a) using 0.1 M HEPES + $0.6 \mathrm{M} \mathrm{NaCl}$ for the $\mathrm{pH}$ range 6-8 and $\mathrm{NaHCO}_{3} / \mathrm{Na}_{2} \mathrm{CO}_{3}$ buffer for higher $\mathrm{pH}$ values. All buffers contained $50 \mathrm{mM}$ $\mathrm{KCl}$. The influence of salt concentration on the activity of thiosulfate oxidation was investigated using soda buffer, $\mathrm{pH}$ 10 , with total $\mathrm{Na}^{+}$concentration from $0 \cdot 3$ to $4 \mathrm{M}$.

Total DNA analysis. The isolation of the DNA and subsequent determination of the $\mathrm{G}+\mathrm{C}$ content of the DNA and the DNA-DNA hybridization were performed according to standard procedures (Marmur, 1961; De Ley et al., 1970).

Amplification and sequencing of 16S rRNA genes. For amplification and sequencing of $16 \mathrm{~S}$ rRNA genes, the DNA was obtained by standard phenol/chloroform extraction. The 16S rRNA genes were selectively amplified using primers 5'-AGAGTTTGATCCTGGCTCAG-3' (forward) and 5'TACGGTTACCT-TGTTACGACTT-3' (reverse). PCR products were cloned, and transformed using InvitroGene kit. Sequencing had been done by MWG Biotech, Inc (High Point North Carolina) with Licor machine using customdesigned primers to sequence samples to an accuracy of $>99 \%$. A combination of both available sequencing reactions which include dye primer on the Licor Long Read IR 4200 sequencers and dye terminator on the ABI3700 capillary sequencers were used. Dye primer chemistry provided data read lengths from 750 to over 1100 bases, while the dye-terminator reaction was used to confirm base calls and provide gap closure with read lengths ranging from 500 to 750 bases. Nearly complete $16 \mathrm{~S}$ rDNA gene sequences were obtained for the Mono Lake isolates ALM $1^{\mathrm{T}}$ and ALM 2 ${ }^{\mathrm{T}}$ (1450-1470 nucleotides).

$16 S$ rDNA sequence analysis. The sequences were aligned manually with sequences obtained from the database of small-subunit rRNAs in EMBL. The sequences were compared with those of the members of the Proteobacteria. Regions that were not sequenced in one or more reference organism were omitted from the analyses. Pairwise evolutionary distances (expressed as estimated changes per 100 nucleotides) were computed by using the Jukes \& Cantor method. A resulting phylogenetic tree was constructed by the neighbour-joining method (Saitou \& Nei, 1987) with bootstrap analysis of 100 trees using programs of the TREECON package (Van de Peer \& De Wachter, 1994). Bootstrap analysis (100 replications) was used to validate the reproducibility of the branching pattern of the trees.

Electron microscopy. For total preparations, cells were washed and resuspended in $0 \cdot 5-1 \mathrm{M}$ neutral $\mathrm{NaCl}$ solution, pre-fixed $(2 \mathrm{~h})$ and then fixed $(10 \mathrm{~h})$ at $4{ }^{\circ} \mathrm{C}$ in $0 \cdot 1 \%$ and $2.5 \%(\mathrm{v} / \mathrm{v}$, final) glutaralaldehyde solutions, respectively, containing the same amount $\mathrm{NaCl}$, and then positively stained with $1 \%(\mathrm{w} / \mathrm{v})$ uranyl acetate. For ultrathin sectioning cells after fixation were postfixed in $1 \%(\mathrm{w} / \mathrm{v})$ $\mathrm{OsO}_{4}$ solution containing $0 \cdot 6-2 \mathrm{M} \mathrm{NaCl}$ for $10 \mathrm{~h}$ at $4{ }^{\circ} \mathrm{C}$. Then the cells were washed, dehydrated and embedded into the resin. Thin sections were stained with $1 \%$ solutions (w/v) of uranyl acetate and lead citrate.

Chemical analysis. Thiosulfate in batch cultures and in experiments with washed cells was determined by the iodimetric titration after acidification of the samples by acetic acid to $\mathrm{pH}$ 5. Sulfide was measured colorimetrically (Trüper \& Schlegel, 1964) after precipitation with zinc acetate $(1 \%, \mathrm{w} / \mathrm{v}$, final). Elemental sulfur was extracted from the cell pellets with acetone overnight and was assayed by a cyanolytic procedure (Sörbo, 1957). The biomass 
protein was determined by the Lowry method, interfering sulfur compounds being removed either by several washings of the cell pellet with $0.6 \mathrm{M} \mathrm{NaCl}$ (thiosulfate) or by a double acetone extraction (elemental sulfur). The pigment from the cells of strain ALM 2 was extracted with a methanol/acetone $(1: 1)$ mixture. Its absorption spectrum was recorded on the UV-Visible diode-array Hewlett Packard HP 8453 spectrophotometer.

\section{RESULTS AND DISCUSSION}

\section{Enrichment and isolation of pure cultures}

Two different positive enrichment cultures from the interface water layer of Mono Lake were obtained using alkaline mineral medium with thiosulfate and different salt content. In low-salt enrichment (0.6 M $\mathrm{Na}^{+}$) a phenotype with coccoid, non-motile cells was seen. Tentative enumeration showed $10^{3}-10^{4}$ cells $\mathrm{ml}^{-1}$. In high-salt enrichment $\left(2.5 \mathrm{M} \mathrm{Na}^{+}\right)$slightly curved motile rods dominanted, and the cultures turned yellowish after complete consumption of thiosulfate and intermediately produced elemental sulfur. Plating of the cultures onto solid media with corresponding salt concentrations resulted in isolation of two different pure cultures of aerobic sulfur-oxidizing bacteria, strains ALM $1^{\mathrm{T}}\left(0 \cdot 6 \mathrm{M} \mathrm{Na}^{+}\right)$and ALM $2^{\mathrm{T}}\left(2 \mathrm{M} \mathrm{Na}^{+}\right)$.

\section{Morphology}

The colonies of strain ALM $1^{\mathrm{T}}$ were up to $3 \mathrm{~mm}$ in diameter, reddish, transparent, without sulfur deposition. Under the light microscope the cells looked like tiny, non-motile, irregular spheres, often aggregated. The electron microscopy demonstrated that the cells of ALM $1^{\mathrm{T}}$ were shaped as the open rings (Fig. 1a, b) with a diameter $0.5-0.8 \mu \mathrm{m}$ and cell width $0.3-0.4 \mu \mathrm{m}$. Many cells contained multiple carboxysome-like structures (Fig. 1a). The colonies of strain ALM $2^{\mathrm{T}}$ were up to $4 \mathrm{~mm}$ in diameter, yellowish, with sulfur deposition. ALM $2^{\mathrm{T}}$ cells are curved rods, $0 \cdot 3-0 \cdot 4 \times 1-2 \mu \mathrm{m}$, motile by a single polar flagellum (Fig. 2a). Cells often contained intracellular sulfur globules (Fig. 2b,c) apparently encapsulated via invagination of the cell membrane (Fig. 2d). The biomass of ALM $2^{\mathrm{T}}$ was yellow-coloured due to membrane-associated pigment. Methanol/acetone extract of the cell membranes had absorption maxima at 405, 430 (main) and $450 \mathrm{~nm}$. The specific pigment content in the biomass increased about twofold when salt content of the growth medium increased from 0.6 to $2-2.5 \mathrm{M}$ total $\mathrm{Na}^{+}$, remaining at constant level upon further increase of salinity to 3-4 $\mathrm{M} \mathrm{Na}^{+}$.

\section{Phylogeny}

Phylogenetic analysis of nearly complete $16 \mathrm{~S}$ rDNA gene sequences of strains ALM $1^{\mathrm{T}}$ and ALM $2^{\mathrm{T}}$ demonstrated their close relationship to two recently described genera of alkaliphilic sulfur bacteria in the $\gamma$ Proteobacteria. Strain ALM $1^{\mathrm{T}}$ is a member of the genus Thioalkalimicrobium with a high level of se-
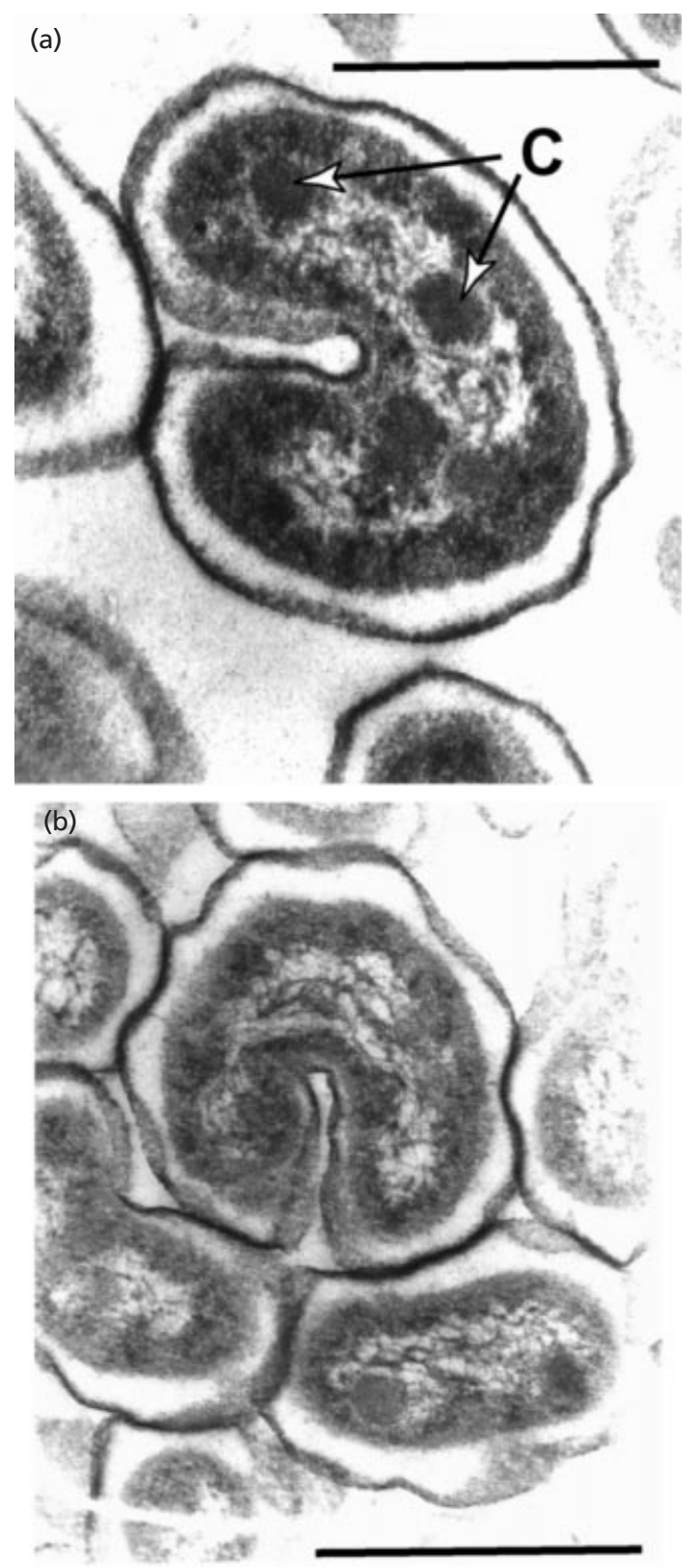

Fig. 1. Morphology of alkaliphilic sulfur bacterium strain ALM $1^{\mathrm{T}}$ from Mono Lake (electron photomicrographs of thin sections; bars, $0.5 \mu \mathrm{m})$ grown with thiosulfate at $\mathrm{pH} 10$ and $0.6 \mathrm{M} \mathrm{Na}^{+}$. C, carboxysome-like structures.

quence similarity to type strains $\mathrm{AL} 3^{\mathrm{T}}$ and $\mathrm{AL} 7^{\mathrm{T}}$ $(96 \cdot 8-98 \cdot 5 \%)$. Strain ALM $2^{\mathrm{T}}$ is more distantly related but definitely belongs to a phylogenetic cluster of the genus Thioalkalivibrio $(92 \cdot 7-96 \cdot 6 \%$ sequence similarity) (Fig. 3).

\section{Genetic analysis}

The results of total DNA analysis of the Mono Lake isolates are given in Table 1 . The $\mathrm{G}+\mathrm{C}$ content in DNA of both strains fitted well into the range typical 

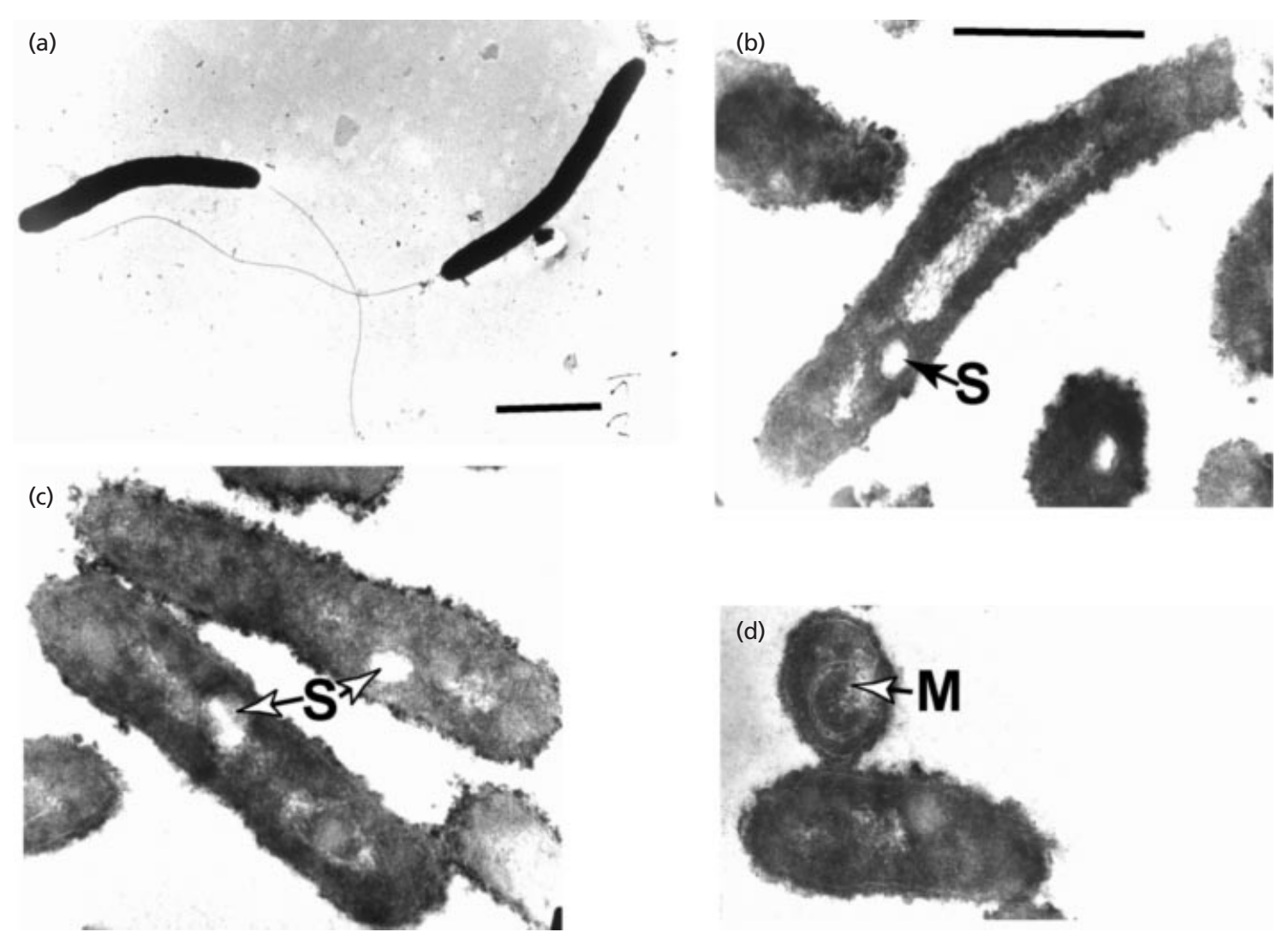

Fig. 2. Morphology of alkaliphilic sulfur bacterium strain $A L M 2^{\top}$ from the Mono Lake (electron photomicrographs) grown with thiosulfate at $\mathrm{pH} 10$ and $2 \mathrm{M} \mathrm{Na}^{+}$. (a) Total preparation (bar, $1 \mu \mathrm{m}$ ); (b)-(d), thin sections (bar, $1 \mu \mathrm{m}$ ). $\mathrm{S}$, Intracellular sulfur globules; M, circular membrane envaginates.

for the corresponding genera of previously described haloalkaliphilic sulfur bacteria. Comparison of total DNA of strain ALM $1^{\mathrm{T}}$ and the type strains of the genus Thioalkalimicrobium confirmed the results of phylogenetic analysis, in that this strain, despite its peculiar morphology, is a member of the genus Thioalkalimicrobium. It had relatively high hybridization to rod-shaped type strain Thioalkalimicrobium aerophilum $\mathrm{AL} 3^{\mathrm{T}}$ but it was still less than is usual between strains of the same species $(<70 \%$; Stackebrandt \& Goebel, 1994). In contrast, strain ALM $2^{\mathrm{T}}$ showed a close phenotypic similarity to the members of genus Thioalkalivibrio, in particular with the yellow coloured, extremely salt-tolerant subgroup, but displayed a very low level of DNA hybridization $(<32 \%)$ with the representative strains of Thioalkalivibrio. Nevertheless, with clear phenotypic and phylogenetic indications, strain ALM $2^{\mathrm{T}}$ should be considered as a member of the genus Thioalkalivibrio.

\section{Physiological properties}

Both Mono Lake isolates belong to obligately chemolithoautotrophic sulfur-oxidizing bacteria. Growth with hydrogen as electron donor and denitrification (thiosulfate + nitrate, nitrite or $\mathrm{N}_{2} \mathrm{O}$ ) were not ob- served. Like other sulfur-oxidizing strains isolated previously from various soda lakes, the Mono Lake isolates were obligately alkaliphilic. Growth in batch culture with thiosulfate at $0.6 \mathrm{M} \mathrm{Na}^{+}$salt content was possible within the $\mathrm{pH}$ range $7 \cdot 5-10 \cdot 5$. The thiosulfatedependent $\mathrm{O}_{2}$ consumption by washed cells of strain ALM $1^{\mathrm{T}}$ and ALM $2^{\mathrm{T}}$ was observed within the $\mathrm{pH}$ range $6 \cdot 5-11$ and $7 \cdot 0-11 \cdot 2$, respectively, with an optimum at $\mathrm{pH} 9.5$ for both organisms (Fig. 4). The salt tolerance of strain ALM $1^{\mathrm{T}}$ was in the moderate range while ALM $2^{\mathrm{T}}$ belongs to an extremely tolerant type, being able to function within a very broad salinity range from 0.4 to $4 \mathrm{M}$ total $\mathrm{Na}^{+}$(Fig. 5). The difference between the strains was more evident with growing cultures (measured by the rate of thiosulfate consumption, Fig. 5a) as compared to activity of the resting cells (Fig. 5b). Strain ALM $1^{\mathrm{T}}$ never formed sulfur as an intermediate during growth with thiosulfate, while prolific sulfur production was observed in ALM $2^{\mathrm{T}}$ cultures at salt concentration less than $2 \mathrm{M}$ total $\mathrm{Na}^{+}$.

The respiratory profiles of both strains (Table 2) are consistent with the patterns of representatives of the genera Thioalkalimicrobium and Thioalkalivibrio. As is typical for members of the genus Thioalkalimicrobium 


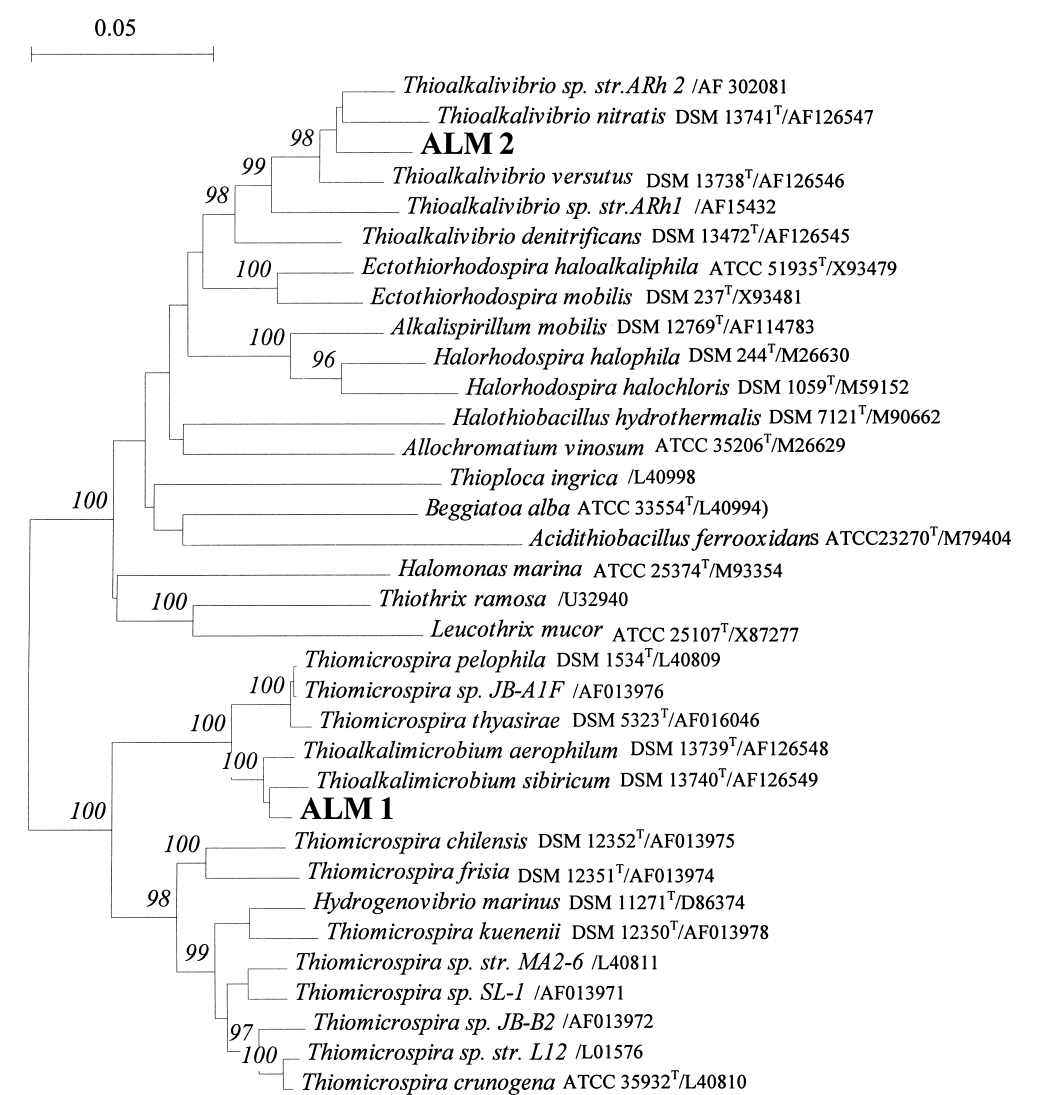

Fig. 3. Phylogenetic tree showing the relationships of the Mono Lake strains of alkaliphilic sulfur-oxidizing bacteria in the $\gamma$-Proteobacteria. The numbers on the branches refer to bootstrap values; only values above $90 \%$ are shown. The bar represents $5 \%$ sequence divergence.

Table 1. DNA-DNA hybridization between Mono Lake isolates and members of genera Thioalkalimicrobium and Thioalkalivibrio

Thioalkalimicrobium: group 1 - Thioalkalimicrobium aerophilum AL 3T; group

2 - Thioalkalimicrobium sibericum AL 7T. Thioalkalivibrio: group 1 - yellow-coloured, extremely salt-tolerant strains from Mongolian, Kenyan and Egyptian soda lakes; group 2 - low-salt tolerant, colourless strains from Kenyan and Siberian soda lakes. Non-specific background values for DNA hybridization (Escherichia coli) was not higher than $5 \%$.

\begin{tabular}{|c|c|c|c|c|c|}
\hline \multirow[t]{3}{*}{ Strain } & \multirow{3}{*}{$\begin{array}{c}\text { DNA G }+\mathbf{C} \text { content } \\
(\mathrm{mol} \%)\end{array}$} & \multicolumn{4}{|c|}{ DNA-DNA hybridization (\%) } \\
\hline & & \multicolumn{2}{|c|}{ Thioalkalimicrobium } & \multicolumn{2}{|c|}{ Thioalkalivibrio } \\
\hline & & Group 1 & Group 2 & Group 1 (8 strains) & Group 2 (6 strains) \\
\hline ALM $1^{\mathrm{T}}$ & $49 \cdot 6$ & 60 & 30 & ND & ND \\
\hline $\operatorname{ALM} 2^{\mathrm{T}}$ & $63 \cdot 7$ & $\mathrm{ND}$ & ND & $25-32$ & $15-20$ \\
\hline
\end{tabular}

ND, No data.

(Sorokin et al., 2001a), strain ALM $1^{\mathrm{T}}$ oxidized thiosulfate and sulfide, less actively polysulfide and tetrathionate and had no activity with elemental sulfur. Strain ALM $2^{\mathrm{T}}$ oxidized all five sulfur compounds with more or less equal but relatively low activity, which is a characteristic of the members of genus Thioalkalivibrio (Sorokin et al., 2001a). Addition of sulfite did not stimulate oxygen consumption in the cell suspensions of the new isolates.
Mono Lake belongs to a comparatively rare type of stratified alkaline and highly saline lakes. In this lake, a hypersaline, anaerobic, sulfide-containing water body is overlaid by less saline, aerobic waters. The result is a rather stable oxic/anoxic interface that has been shown to act as an active aerobic chemolithotrophic 'filter' for reduced inorganic compounds, such as ammonia, methane and sulfide (Joye et al., 1999; Ward et al., 2000). Given the high sulfate 


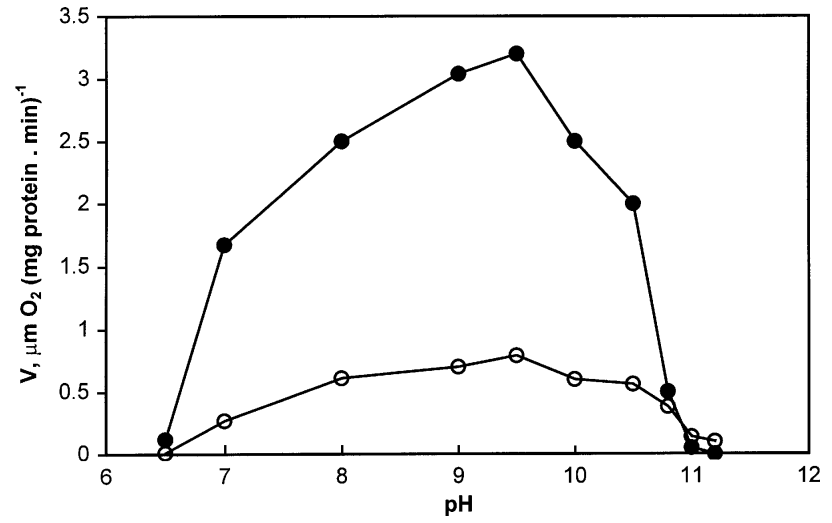

Fig. 4. Influence of $\mathrm{pH}$ on the activity of thiosulfate-dependent oxygen consumption by washed cells of the Mono Lake isolates ALM $1^{\top}(\bigcirc)$ and ALM $2^{\top}(O)$. All buffers contained $0.6 \mathrm{M}$ total $\mathrm{Na}^{+}$. pH 6.5-8, HEPES + NaCl; pH 8-11.2, $\mathrm{NaHCO}_{3} / \mathrm{Na}_{2} \mathrm{CO}_{3}$. Means from the two independent experiments.
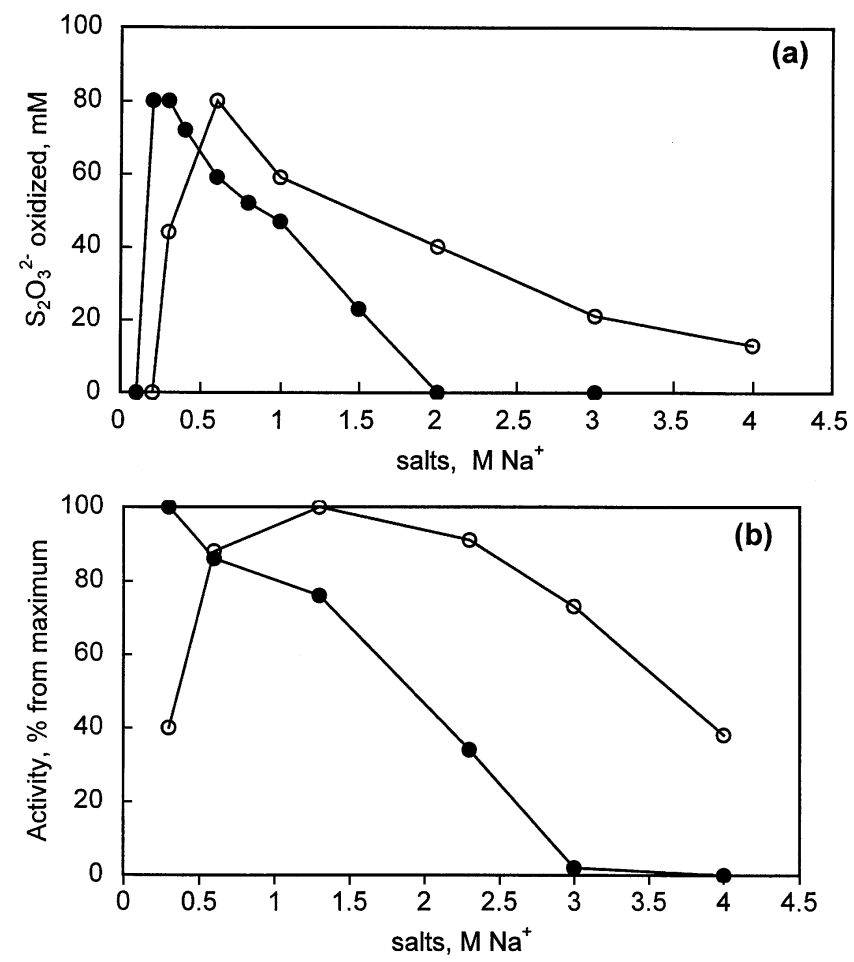

Fig. 5. Influence of salt concentration $\left(\mathrm{NaHCO}_{3} / \mathrm{Na}_{2} \mathrm{CO}_{3} / \mathrm{NaCl}\right)$ on growth and activity of thiosulfate oxidation by washed cells of the Mono Lake isolates at $\mathrm{pH}$ 10. (a) Amount of thiosulfate consumed during 24 and $47 \mathrm{~h}$ growth in batch cultures of the strains ALM $1^{\top}$ and ALM $2^{\top}$, respectively; (b) activity of thiosulfate-dependent respiration. $\operatorname{ALM} 1^{\mathrm{T}} ; 0, \operatorname{ATM}^{\mathrm{T}}$. Means from the two independent experiments.

concentration (130 mM) (Oremland \& Miller, 1993), the presence of sulfur-oxidizing bacteria in the redox interface of Mono Lake was suspected as well. Our investigation demonstrated that at least two different
Table 2. Respiration rate of washed cells

ALM $1^{\mathrm{T}}$ and ALM $2^{\mathrm{T}}$ were grown with thiosulfate at $\mathrm{pH} 10$ and $0.6 \mathrm{M} \mathrm{Na}^{+}$. Values are given as $\mu \mathrm{mol} \mathrm{O}_{2}(\mathrm{mg} \text { protein })^{-1}$ $\mathrm{min}^{-1}$ (means of 2-3 independent measurements); endogenous rates were subtracted.

\begin{tabular}{|lcc|}
\hline \multirow{2}{*}{ Substrate } & \multicolumn{2}{c|}{ Respiration rate } \\
\cline { 2 - 3 } & ALM 1 & ALM 2 \\
& & \\
\hline Thiosulfate $\left(\mathrm{S}_{2} \mathrm{O}_{3}^{2-}\right)$ & $2 \cdot 50$ & 0.60 \\
Sulfide $\left(\mathrm{HS}^{-}\right)$ & $3 \cdot 04$ & $0 \cdot 70$ \\
Polysulfide $\left(\mathrm{S}_{6}^{2-}\right)$ & $1 \cdot 80$ & $0 \cdot 66$ \\
Sulfur $\left(\mathrm{S}_{8}\right)$ & $0 \cdot 00$ & 0.52 \\
Tetrathionate $\left(\mathrm{S}_{4} \mathrm{O}_{6}^{2-}\right)$ & $0 \cdot 42$ & $0 \cdot 33$ \\
\hline
\end{tabular}

cultivable types of obligately chemolithoautotrophic, aerobic, haloalkaliphilic sulfur bacteria inhabit this lake. One type (represented by strain ALM $1^{\mathrm{T}}$ ), enriched at moderate salt concentration, probably corresponds to a population adapted to the surface aerobic waters of the Mono Lake mixolimnion. The other type (represented by strain ALM $2^{\mathrm{T}}$ ), enriched at extremely high salt concentrations, functions optimally at 1-3 $\mathrm{M} \mathrm{Na}^{+}$, which encompasses the salt content of the monimolimnion $\left(1.4 \mathrm{M} \mathrm{Na}^{+}\right)$but also would allow such bacteria to survive a local increase of salinity. Such conditions may occur in the shallow evaporative pools temporarily separated from the main lake water body.

Unlike many other freshwater and saline stratified shallow lakes (where sufficient light penetrates to a sulfide-containing layer), in Mono Lake the anaerobic sulfide-oxidizing phototrophs do not build up a substantial population (V. Gorlenko, unpublished). The reasons are not quite clear. It could be presence of unusually high concentrations of toxic oxyanions, such $\mathrm{AsO}_{4}^{2-}$ and $\mathrm{SeO}_{3}^{2-}$ (Stolz \& Oremland, 1999) or light interception by the abundant mixolimnion population of the unicellular algae 'Picocystis salinarium', which was recently discovered in the Mono Lake ecosystem (http://www.monobasinresearch.org/research/ microbial). Whatever the reason, in the absence of active population of anaerobic phototrophs it might be speculated that the aerobic, haloalkaliphilic, sulfuroxidizing bacteria play a key role in the oxidation of sulfide coming up from the anaerobic layer in Mono Lake.

On the basis of physiological and genetic properties, the Mono Lake isolates were clearly related to two different groups of previously described haloalkaliphilic sulfur-oxidizing bacteria isolated from the Kenyan and Siberian soda lakes (Sorokin et al., 2001a). Strain ALM $1^{\mathrm{T}}$, being physiologically very similar to representatives of the genus Thioalkalimicrobium, differs from the known species of this genus by its morphology. Phylogenetically strain ALM $1^{\mathrm{T}}$ is closely related to members of the genus Thioalkalimicrobium 
but since its DNA similarity with described species was less than $70 \%$, this strain is proposed as a new species, Thioalkalimicrobium cyclicum. Strain ALM $2^{\mathrm{T}}$, despite its very low DNA hybridization with the representative strains, phenotypically clearly resembles the extremely salt-tolerant members of the genus Thioalkalivibrio. In view of the results of phylogenetic analysis, this isolate should be affiliated with the genus Thioalkalivibrio and is proposed as a new species Thioalkalivibrio jannaschii. We have also found this type of sulfur-oxidizing double extremophiles dominating in highly saline alkaline lakes in Mongolia, Kenya and Wadi an Natrun in Egypt (Sorokin et al., 2001a; our unpublished results). It is interesting to mention that these sulfur-oxidizing bacteria probably represent the only type of aerobic chemolithoautotrophs capable to grow in saturated alkaline brines. Other types of alkaliphilic chemolithoautotrophs (methane-, hydrogen-, ammonia- and nitrite-oxidizing), although being detected in and isolated from the extremely saline soda lakes, are able to grow only at salinity below $1 \mathrm{M} \mathrm{Na}^{+}$(Ward et al., 2000; Sorokin et al., 1998, 2000a, c, 2001c).

\section{Description of Thioalkalimicrobium cyclicum sp. nov.}

Thioalkalimicrobium cyclicum (cyc.li'cum Gr. n. cyclus circle; M.L. n. cyclicum circle-like).

Cells are mostly in a form of open ring with a diameter $0 \cdot 5-0.8$ and cell width $0 \cdot 3-0 \cdot 4 \mu \mathrm{m}$. Many cells contained multiple carboxysome-like structures. Obligately chemolithotrophic, alkaliphilic and moderately halophilic. Grows up to $1.5 \mathrm{M} \mathrm{Na}^{+}$. Oxidizes sulfide, thiosulfate, polysulfide and tetrathionate. $\mathrm{G}+\mathrm{C}$ content in DNA is $49.6 \mathrm{~mol} \%\left(T_{\mathrm{m}}\right)$. Isolated from the $\mathrm{O}_{2}$-sulfide interface layer of Mono Lake (California, USA). Other properties as for the genus. The type strain is ALM $1^{\mathrm{T}}\left(=\mathrm{DSM} 14477^{\mathrm{T}}=\mathrm{JCM} 11371^{\mathrm{T}}\right)$.

\section{Emended description of genus Thioalkalimicrobium}

The description of the genus Thioalkalimicrobium (Sorokin et al., 2001a) should be emended by the following:

Cells vary in shape from straight rods with sharp edges to spirilla, $0.3-0.5 \times 0.8-1.5 \mu \mathrm{m}$, motile by means of 1-3 polar flagella at one end. Also includes strains with non-motile, circular and coccoid cells.

\section{Description of Thioalkalivibrio jannaschii sp. nov.}

Thioalkalivibrio jannaschii (jann.asch'i.i. N.L. gen. n. jannaschii in honour of German microbiologist Holger Jannasch).

Cells are curved rods, $0 \cdot 3-0 \cdot 4 \times 1-2 \mu \mathrm{m}$, motile by a single polar flagellum. Cells often contain intracellular sulfur globes when grown with thiosulfate at low salinity. Produces yellow, membrane-associated pigment during growth at high salinity. The methanol/ acetone extract of the cell membranes has absorption maxima at 405, 430 (main) and $450 \mathrm{~nm}$. Obligately chemolithoautotrophic, haloalkaliphilic bacterium. Tolerates up to $4 \mathrm{M} \mathrm{Na}^{+}$. Oxidizes sulfide, thiosulfate, polysulfide, sulfur and tetrathionate. $\mathrm{G}+\mathrm{C}$ content in DNA is $63.7 \mathrm{~mol} \%\left(T_{\mathrm{m}}\right)$. Isolated from the $\mathrm{O}_{2}$-sulfide interface layer of alkaline Mono Lake (California). Other properties as for the genus. The type strain is $\operatorname{ALM} 2^{\mathrm{T}}\left(=\operatorname{DSM} 14478^{\mathrm{T}}=\mathrm{JCM} 11372^{\mathrm{T}}\right)$.

\section{ACKNOWLEDGEMENTS}

This work was financially supported by The Netherlands Organization for Scientific Research (NWO Project 047.006.018) and RFBR (99-04-48707 and 01-04-48782). Part of this work was performed at the Jet Propulsion Laboratory/California Institute of Technology, with support from DRDF grant 100656-00888. We thank Diane Engler for technical assistance.

\section{REFERENCES}

De Ley, J., Caffon, H. \& Reinaerts, A. (1970). The quantitative measurements of DNA hybridization from renaturation rates. Eur $J$ Biochem 12, 133-140.

Jones, B. E., Grant, W. D., Duckworth, A. W. \& Owenson, G. G. (1998). Microbial diversity of soda lakes. Extremophiles 2, 191-200.

Joye, S. B., Conell, T. L., Miller, L. G., Oremland, R. S. \& Jellison, R. S. (1999). Oxidation of ammonia and methane in an alkaline, saline lake. Limnol Oceanogr 44, 178-188.

Kelly, D. P. (1989). Physiology and biochemistry of unicellular sulfur bacteria. In Autotrophic Bacteria, pp. 193-217. Edited by H. G. Schlegel \& B. Bowien. Berlin: Springer.

Kuenen, J. G., Robertson, L. A. \& Tuovinen, O. H. (1992). The genera Thiobacillus, Thiomicrospira and Thiosphaera. In The Prokaryotes, 2nd edn, vol. 3, pp. 2638-2657. Edited by A. Balows, H. G. Trüper, M. Dworkin, W. Harder \& K. Schleifer. Berlin: Springer.

Marmur, J. (1961). A procedure for isolation of DNA from microorganisms. J Mol Biol 3, 208-214.

Oremland, R. S. \& Miller, L. G. (1993). Biochemistry of natural gases in three alkaline, permanently stratified (meromictic) lakes. In The Future of Energy Gases (USGS professional paper 1570), pp. 439-452. Edited by D. Howell. Reston, VA: USGS.

Saitou, N. \& Nei, M. (1987). The neighbor-joining method: a new method for constructing phylogenetic trees. Mol Biol Evol 4, 406-425.

Sörbo, B. (1957). A colorimetric determination of thiosulfate. Biochim Biophys Acta 23, 412-416.

Sorokin, D. Y., Lysenko, A. M. \& Mityushina, L. L. (1996). Isolation and characterization of alkaliphilic heterotrophic bacteria capable of oxidation of inorganic sulfur compounds to tetrathionate. Microbiology (English translation of Mikrobiologiya) 65, 326-338.

Sorokin, D. Y., Muyzer, G., Brinkhoff, T., Kuenen, J. G. \& Jetten, M. (1998). Isolation and characterization of a novel facultative alkaliphilic Nitrobacter species, N. alkalicus sp. nov. Arch Microbiol 170, 345-352.

Sorokin, D. Yu., Jones, B. E. \& Kuenen, J. G. (2000a). A novel, obligately methylotrophic, methane-oxidizing Methylomicrobium sp. from highly alkaline environment. Extremophiles 4, 145-155.

Sorokin, D. Y., Robertson, L. A. \& Kuenen, J. G. (2000b). Isolation and characterization of obligately chemolithoautotrophic alkaliphilic sulfur-oxidizing bacteria. Antonie Leeuwenhoek 77, 251-260.

Sorokin, D. Yu., Tourova, T. P. \& Kuenen, J. G. (2000c). A novel facultatively autotrophic hydrogen-and sulfur-oxidizing bacterium from alkaline environment. Extremophiles 4, 237-245. 
Sorokin, D. Yu., Lysenko, A. M., Mityushina, L. L., Tourova, T. P., Jones, B. E., Rainey, F. A., Robertson, L. A. \& Kuenen, G. J. (2001a). Thioalkalimicrobium aerophilum gen. nov., sp. nov. and Thioalkalimicrobium sibericum sp. nov., and Thioalkalivibrio versutus gen nov., sp. nov., Thioalkalivibrio nitratis sp. nov. and Thioalkalivibrio denitrificans sp. nov., novel obligately alkaliphilic and obligately chemolithoautotrophic sulfur-oxidizing bacteria from soda lakes. Int $J$ Syst Evol Microbiol 51, 565-580.

Sorokin, D. Yu., Tourova, T. P., Lysenko, A. M. \& Kuenen, J. G. (2001b). Microbial thiocyanate utilization under highly alkaline conditions. Appl Environ Microbiol 67, 528-538.

Sorokin, D. Yu., Tourova, T. P., Schmid, M., Wagner, M., Koops, H.-P., Kuenen, J. G. \& Jetten, M. (2001c). Isolation and properties of obligately chemolithoautotrophic alkaliphilic ammonia-oxidizing bacteria from Mongolian soda lakes. Arch Microbiol 176, 170-177.

Sorokin, D. Yu., Tourova, T. P., Lysenko, A. M., Mityushina, L. L. \& Kuenen, J. G. (2002). Thioalkalivibrio thiocyanoxidans sp. nov. and Thioalkalivibrio paradoxus sp. nov., novel alkaliphilic, obligately autotrophic, sulfur-oxidizing bacteria capable of growth on thiocyanate, from soda lakes. Int J Syst Evol Microbiol 52, 657-664.
Stackebrandt, E. \& Goebel, B. M. (1994). Taxonomic note: a place for DNA-DNA reassociation and 16S rRNA sequence analysis in the present species definition in bacteriology. Int $J$ Syst Bacteriol 44, 846-849.

Stolz, J. F. \& Oremland, R. S. (1999). Bacterial respiration of arsenic and selenium. FEMS Microbiol Rev 23, 615-627.

Trüper, H. G. \& Schlegel, H. G. (1964). Sulphur metabolism in Thiorhodaceae. Quantitative measurements on growing cells of Chromatium okeanii. Antonie Leeuwenhoek 30, 225-237.

Van de Peer, Y. \& De Wachter, R. (1994). TREECON for Windows: a software package for the construction and drawing of evolutionary trees for the Microsoft Windows environment. Comput Appl Biosci 10, 569-570.

Ward, B. B., Martino, D. P., Diaz, M. C. \& Joye, S. B. (2000). Analysis of ammonia-oxidizing bacteria from a hypersaline Mono Lake, California, on the basis of $16 \mathrm{~S}$ rRNA sequences. Appl Environ Microbiol 66, 2873-2881.

Zavarzin, G. A., Zhilina, T. N. \& Kevbrin, V. V. (1999). The alkaliphilic microbial community and its functional diversity. Microbiology (English translation of Mikrobiologiya) 68, 503-521. 